\title{
Factors Affecting Chickpea Market Chain: The Case of Dembia District, North Gondar Zone, Ethiopia
}

\author{
GEDEFAW ABEBE ${ }^{1}$ SISAY DEBEBE ${ }^{2}$ \\ 1.College of Agriculture and Natural Resource, Department of Agricultural Economics, \\ Bonga University P.O. Box: 334, Bonga, Ethiopia \\ 2.College of Business and Economics, Department of Economics, Arba Minch University \\ P.O.Box: 21, Arba Minch, Ethiopia
}

\begin{abstract}
Chickpea is the 4th largest foreign currency earning crop of Ethiopia following coffee, sesame and haricot bean and the major cash crop grown in the study area mainly for market. This study was aimed to examine analysis of chickpea market chain in Dembia district. For analysis both primary and secondary data were employed. The primary data were collected from 150 chickpea producers and 30 traders by individual interview schedule based on two stage random sampling. Heckman two-stage model was used to identify factors affecting market participation and volume of sale of chickpea. As the result indicates, the age of household head and non-farm income have affected market participation decision and volume of sale negatively and significantly while education level of the household head, access to market information, farming experience, land allocated to chickpea and lagged market price have been influenced market participation and volume of supply of chickpea positively and significantly. Based on the findings, the government and other policy makers have to increase marketing information and ability of chickpea farmers through opportunities like mass media, extension service, and other means of capacity building.
\end{abstract}

Keywords: Heckman Two-step model, Market Participation, Volume of Sale of Chickpea, and Dembia, Ethiopia. DOI: $10.7176 / \mathrm{JMCR} / 66-02$

Publication date:March $31^{\text {st }} 2020$

\section{INTRODUCTION}

Ethiopian economy and employment are largely depending on agriculture sector. This sector stimulates the overall economic development of the country (Desalegn, 2019). Its gross domestic product (GDP) reached 55 billion dollar and per capital was 631 dollar by the end of 2013/14. Agriculture, industry and services sectors contributed $40 \%, 14 \%$ and $46 \%$, respectively to the GDP. In the total employment opportunities, $72.7 \%$ was generated from agriculture sector and the other $19.8 \%$ and $7.4 \%$ generated from service and industry sectors, in sequence, (UNDP, 2015). The contribution of agriculture to GDP over the years is declining; through it is the leading sector in the contribution to the country's overall economy (UNDP et al., 2016). Chickpea is cultivated above 40 countries of the globe around 11 million ha of land from which over 8 million tons of seed is yearly harvested (Menale et al., 2010), and chickpea is widely grown in Ethiopia, Sudan, Eritrea, Kenya, Tanzania and Malawi. It contributes around $63 \%$ of the total production in Africa. In Ethiopia, chickpea ranks third in area coverage from among the pulses grown areas and proceeded by Faba bean and Field pea and second in volume of production only next to Faba bean. In the country, with a total area of $229,720.74$ ha land and the productivity of 1.85 ton per hectare (CSA, 2014; TL-III, 2016).

Chickpea marketing system in Ethiopia is highly underdeveloped and poorly organized. The crop utilization report of CSA indicated that 56.86 percent of total chickpea production was estimated to be allocated for household consumption of the producers and the domestic and export market account for 23.53 percent of the total chickpea volume produced (CSA, 2007). This implies that the nature of production is subsistence. Although chickpea is widely grown in Ethiopia, the major producing areas are concentrated in the two regional states - Amhara and Oromia. These two regions cover more than $90 \%$ of the entire chickpea area and constitute about $92 \%$ of the total chickpea production. The top 9 chickpea producing zones (north Gonder, south Gonder, north Shewa, east Gojjam, south Wello, north Wello, west Gojjam, Gonder Zuria) belong to the Amhara region and account for about $80 \%$ of the country's chickpea production(CSA, 2015). According to the report of Office of Agriculture and rural development of the district (2016/2017), the major crops grown in the District include maize, Teff, wheat, sorghum, barley, millet, chickpea, Niger, pepper, black cumin and nechazmud. The major crops supplies to the market in the woreda are Teff, pepper, chickpea, black cumin, and nechazmud. According to (James et al., 2015) Dembia district on average ranked the first in production of chickpea out of 25 districts in Ethiopia in 2013.

(Muhammed, 2011) also clearly states that the knowledge gaps in the crop sector in Ethiopia were inefficiency of the market system. Based on information obtained from (Dembia district agriculture office, 2017), pulse marketing in the district is characterized by inefficient market. It has been constrained with lots of problems such as unstable prices, inadequacy of product handing practices especially in the surplus production areas, poor purchasing power of consumers in the urban areas, competition from unlicensed traders, lack of road and poor 
transportation facilities, poor linkages with traders, low quality controlling mechanisms, weak market information and other factors need to be further investigated thoroughly and alternative solution need to be suggested and implemented so as to benefit producers and other marketing agents involved in the production of pulse crops. Despite the potential of the District for pulse production, its productivity is low due to use of low level of improved agricultural technologies, risks associated with climatic conditions, diseases and pests. Moreover, lack of organized market system frequently resulted in low producers' price. Analysis of chickpea value chain was undertaken by (Bekele, 2007) Moreover there is a need to employ a commodity market to fully understand and resolve the problem of chickpea at all levels. This makes undertaking analysis of chickpea marketing and to address the prevailing information gap on chickpea market participation, and volume of sale in the study area.

\section{METHODOLOGY}

\subsection{Description of the Study Area}

The study was conducted in Dembia district of north Gondar zone, Amhara region, Ethiopia. Dembia is one of the 16 districts found in north Gondar zone. The study area is located $750 \mathrm{~km}$ north of Addis Ababa and $35 \mathrm{~km}$ southwest of Bahir Dar, Gondar. Towns' administration in Dembia district includes Aymiba, Chuahit, Gorgora and Koladiba. The District shares borders with Gondar town and Lay Armachiho in the north, Gondar Zuria district in the east, Chilga and Alefa districts in the west and part of Lake Tana in the south. Dembia district is located at $37^{0} 26^{`}$ E longitude and $12^{\circ} 17^{`} \mathrm{~N}$ latitude. Total area of the district is $1490 \mathrm{~km} 2$ with 40 rural and 5 urban kebeles total of 45 kebeles (DDFEDO, 2017).

Fig2: Map of study area

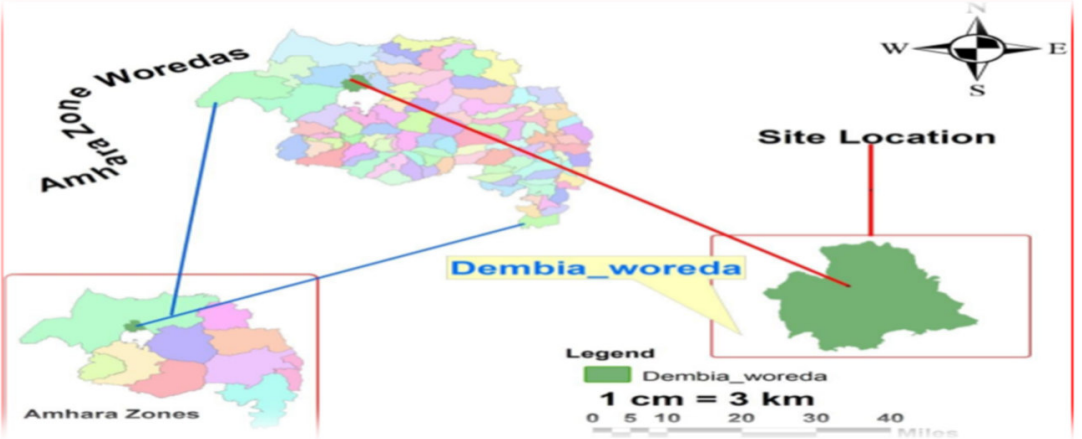

Source: Bureau of Finance \& Economic Development, 2018

Figure 1: Location map of Dembia district

The District has total 321,874 populations out of which 286,673 live in rural and 35200 live in urban. Out of the total population 160,124 are male and 161,750 are female. The majority of the population practiced Ethiopian orthodox Christianity, with $98.3 \%$ while $1.7 \%$ of the population said they were Muslim (DDFEDO, 2017).

\subsection{Sample Size and Techniques}

A two stage sampling procedure was employed to select potential chickpea producer households. First, five potential producer kebeles were selected from 40 chickpea producer kebeles via purposive sampling method. In the second stage, using the population list of chickpea producer farmers from sample kebeles, the intended sample size was determine proportionally to population size of chickpea producer farmers from the sample frame of the selected kebeles. Then 150 sample size was determined by Cochran's (1977): $n=\frac{z^{2} q p}{e^{2}}$.

\subsection{Method of Analysis}

For analysis of the data, simple descriptive statistics and econometrics skills were applied. Simple descriptive statistics such as mean, standard deviation, frequency and inferential statistics techniques such as t-test, and chisquare test were applied and heckman two stage econometrics models were used using STATA as a tool of analysis.

\subsection{Two Stage Heckman Mode Specification}

Econometric analysis was used for processing the data. The appropriate models to identify the factors affecting market participation decision and volume of supply are Tobit or Heckman Two-stage (Gujarati 2004; Heckman 1979). Heckman Two-Stage model was employed because of its advantages over the Tobit model in its ability to eliminate selectivity bias and it separates the effect of variables on the probability of market participation from the effect on the volume of chickpea that was sale (Heckman, 1979). Using the Heckman two stage models, the first stage is market participation equation, which helps to identify factors affecting chickpea market participation decision using Probit. Then in the second stage, OLS regression was used to determine the volume of market supply of chickpea. 
The probability of a household's head to participate in supplying of chickpea is given by the selection equation as: $y i=\beta i x i+\varepsilon$ Equation (1)

Where $\varepsilon_{i} \sim \mathrm{N}(0,1), \mathrm{i}=1,2 \ldots \mathrm{n}$, yi = a dummy variable that takes a value of 1 if a household's head has participated and 0 otherwise. $\beta_{i}=$ Parameters to be estimated in the model, $\mathrm{x}_{\mathrm{i}}=$ explanatory variables that can affect market participation $\varepsilon_{i}=$ error term normalized to 1 since a farmer who participated is observed and normally distributed (with correlation coefficient, $\rho$ ).

The chickpea market supply was given by the following equation by including an estimate of the inverse Mill's Ratio $(\lambda \mathrm{j})$ as: $y j=\beta i x i+\lambda j \mu+\varepsilon j$ equation (2)

Where $\varepsilon_{i} \sim \mathrm{N}\left(0, \delta^{2}\right), \mathrm{y}_{\mathrm{j}}=$ the amount of chickpea market supply and observed if only participation is yes, that is $\mathrm{y}_{\mathrm{j}}=1, \beta_{\mathrm{j}}=$ Unknown parameter to be estimated in the outcome equation, $\mathrm{xj}=$ Explanatory variable that can affect the amount of chickpea supply, $\lambda=$ A correction factor for selection bias (Inverse Mill's Ratio)i.e $\lambda=$ $\mathrm{f}\left(\frac{\mathrm{yi}}{1-f(y i)}\right), \varepsilon \mathrm{j}=$ Error term, and normally distributed with correlation coefficient, $\delta^{2}$. If IMR is insignificant, interpretation of the results from the Heckman two-step procedure was not relevant for the fact that the procedure is highly sensitive to model misspecification.

\subsection{Variable definition, measurement and working hypothesis}

Market participation decision is the dummy dependent variable in the first stage of the Heckman two stage estimation procedures. For the respondents who participate in chickpea market it is $=1$, and $=0$ other wise in 2018/19 production year and Market supply is continuous dependent variable in the second stage of Heckman twostage estimation equation (Kinde, 2007; Rehima, 2007; Abay, 2007, Astewel, 2010; Abraham, 2013; Geoffrey, 2014))

Table 1: Description, measurement and effect of variables for market participation, and volume of sales:

\begin{tabular}{|c|c|c|c|c|}
\hline \multirow[t]{2}{*}{ Variables } & \multirow[t]{2}{*}{ Description } & \multirow[t]{2}{*}{ Measurement } & \multicolumn{2}{|l|}{ Effect variables } \\
\hline & & & Market participation & Volume of sale \\
\hline AGE & Age of household head & Year & + & + \\
\hline SEX & Sex of household head & $1=$ male, $0=$ female & + & + \\
\hline FS & Family size & Man equivalent & + & + \\
\hline LITERACY & Education level & Categorical variable & + & + \\
\hline $\mathrm{EXC}$ & Extension contact & $0=$ no, $1=$ yes & + & + \\
\hline DFM & Distance from market & Walking minutes & - & - \\
\hline LMP & Lagged market price & $\begin{array}{l}\text { Lagged price of } \\
\text { chickpea in birr }\end{array}$ & + & + \\
\hline TQP & Quantity produced & $\begin{array}{l}\text { Amount of chickpea } \\
\text { produced in quintal }\end{array}$ & + & + \\
\hline $\mathrm{LACH}$ & $\begin{array}{l}\text { Land allocation to } \\
\text { chickpea }\end{array}$ & $\begin{array}{l}\text { land allocated in } \\
\text { hectares }\end{array}$ & + & + \\
\hline MINF & $\begin{array}{l}\text { Access to market } \\
\text { information }\end{array}$ & $0=$ yes, $1=$ otherwise & + & + \\
\hline CREDIT & Credit access & Amount of credit in birr & + & + \\
\hline NFINC & Non-farm income & Nonfarm income in birr & - & - \\
\hline TLU & Total livestock holding & Discrete variable & + & + \\
\hline Own Tran & Owner transport asset & $1=$ Yes, $0=$ No & + & + \\
\hline Own corn & $\begin{array}{l}\text { Owner ship of } \\
\text { communication device }\end{array}$ & $\begin{array}{l}\text { Owner ship of } \\
\text { communication device }\end{array}$ & + & + \\
\hline
\end{tabular}

\section{RESULTS AND DISCUSSIONS}

\subsection{Descriptive Statistics Results}

\subsubsection{Demographic and socio-economic trait to market participation}

Table 2 indicates that the average age of market participants was 44 years while that of non-market participants 50 years. The overall mean age of chickpea farmers was 45 years old. The result of t-test shows that age was statistically significant at 5\% significance level. This indicates there is an association between market participant and non-participant. Family labor of market participants were 4.9 man equivalents, while for non-market participants 4.08 man equivalent. The overall mean was 4.26 man equivalents. The result of t-test showed that family labor is statistically significant at $5 \%$ significance level. This means that the mean family labors owned by market participants are greater than that of non-market participants. 
Average land size owned by market participants was 1.84 hectares, while that of non-market participants was 1.40 hectares. The overall mean of land size owned by sample farmers was 1.75 hectares. The result of t-test indicates that land size is statistically significance at 5\% significance level. This means that the mean land sizes owned by market participants are greater than that of non-market participants. Therefore, land is the single most important factor of production and a measure of wealth in the study area.

The mean of chickpea yield produced by market participants per year was 10.07 quintals while that for nonmarket participants was 4.695 quintals. The overall mean of chickpea yield was 8.93 quintals. The result of t-test shows that chickpea yield was statistically significant at $1 \%$ significance level. This indicates that the market participants had more chickpea yield than non-market participants. The result is consistent with the findings of (Astewel, 2010) and (Geoffrey, 2014) who confirmed that increasing the volume of production increases market participation. TLU owned by market participants was 4.6899 numbers, while that for non-market participants was 3.38 numbers. The overall mean of TLU owned by the sample household farmers were 4.41 numbers. The result of t-test shows that number of TLU owned was statistically significant at 5\% significance level. This indicates that market participant farmers owned more numbers of TLU than non-market participant farmers. TLU increases agricultural production and productivity. This implies that increasing the volume of production increases the market participation of farmers. As the result indicates that the mean of distance to the nearest market for market participant was 73.81 minutes, while that of non-market participant was 80.47 minutes. The overall mean of distance to the nearest market for sample respondents was 75.23 minutes. The result of t-test shows that distance to the nearest market was statistically in significant. Meaning that distance from nearest market between market participants and non-market participants were almost equal.

Table 2: demographic and socio-economic characteristics of target respondents for continuous variables

\begin{tabular}{|c|c|c|c|c|c|c|c|}
\hline \multirow[t]{2}{*}{ Variables } & \multicolumn{4}{|c|}{$\begin{array}{l}\text { Market Participant( } \mathrm{N}=118) \text { Non-Market } \\
(\mathrm{N}=32) \\
\text { Participant }\end{array}$} & \multirow[t]{2}{*}{$\begin{array}{l}\text { Overall } \\
\text { mean }\end{array}$} & \multirow[t]{2}{*}{ t-test } & \multirow[t]{2}{*}{ Sig. } \\
\hline & Mean & Std. Dev. & Mean & Std. Dev. & & & \\
\hline Age & 43.85 & 12.60 & 49.94 & 13.11 & 45.15 & 2.40 & $.0175 * *$ \\
\hline Family labor & 4.91 & 1.9896 & 4.085 & 2.277 & 4.26 & 2.008 & $.0465 * *$ \\
\hline Land size & 1.84 & .96 & 1.40 & .763 & 1.75 & -2.38 & $.0185 * *$ \\
\hline TLU & 4.6899 & 3.46 & 3.38 & 2.12 & 4.41 & -2.045 & $.0426 * *$ \\
\hline Distance from nearest market & 73.81 & 33.37 & 80.47 & 34.42 & 75.23 & 0.995 & .3213 \\
\hline Yield & 10.07 & 5.827 & 4.695 & 4.45 & 8.93 & -4.85 & $.0000 * * *$ \\
\hline
\end{tabular}

Note: $* * * * * \quad$ indicates at $1 \%, 5 \%$ significance level in sequence.

Source: own survey, 2018

The total sample size of the farm respondents handled during the survey was 150 . Out of the total sample respondents, $75.3 \%$ were male headed households and $24.7 \%$ were female headed households (Table 3 ). In terms of market participation, $61.33 \%$ of market participant were male headed, while $17.33 \%$ were female headed. On the other hand, $21 \%$ of non-market participants were male headed households, while $7.3 \%$ of non-market participants were female headed households. As the result of chi-square indicates sex of sample households was statistically insignificant meaning that the sex was not affect the market participation of households. Majorities of sample respondents were male headed households in the study area. This implies that the participation of females in chickpea cultivation was very low; this might be related with unequal distribution of resources as well as cultural barriers and belief of the society. The result in table 3 indicates that $43.3 \%$ of market participants were got credit access; while $35.3 \%$ were not get credit. On the other hand, $10.7 \%$ of non-market participants was get credit access, while $8.7 \%$ of was not get credit access. The overall access to credit status of sample respondents were dominated by credit access users, which accounts $54 \%$ and the remaining $46 \%$ was not get credit access. The result of chisquare test shows that credit access of sample households was statistically insignificant meaning that access to credit was not affect the market participation of sample households.

$53.3 \%$ of market participants were utilized improved inputs as the result indicates, while $25.3 \%$ was not used improved inputs. On the other hand $8.7 \%$ of non-market participants were utilized improved inputs, while the remaining $12.7 \%$ was not utilized improved inputs. The overall agricultural input use status of sample households was dominated by improved input users, which accounts $62 \%$ and the remaining $38 \%$ was non-users. The result of chi-square shows that the use of improved input was statistically significant at $1 \%$ significance level. The use of agricultural inputs increases the volume of production.

The result in table 3 indicates that $67.3 \%$ of market participants was get market information, while $11.3 \%$ was not get market information. On the other hand, $14,7 \%$ of non-market participants were get market information, while $6.7 \%$ was not get market information. About $82 \%$ of sample households revealed that they got market information of the nearby market before they sold their product from local traders, neighbors and cooperatives. The result of chi-square shows that access to market information of sample households was statistically significant 
at $5 \%$ significance level. Access to market information increases market participation of farmers. The result shows that about $43.3 \%$ of the sample respondents had an access on extension service of marketing while $46.7 \%$ did not get access. The result of chi-square test shows that access to extension service on marketing of sample households was statistically significant at $1 \%$ significant level. Access to extension service on marketing increase market participation. The result indicates that about $22.7 \%$ of market participants were engage in non-farm activities, while $56 \%$ was not engage in non-farm activities. On the other hand, $11.3 \%$ of non-market participants were engage in non-farm activities, while $10 \%$ was not engage in non-farm activities.

The overall status of sample farmers related to engaging in non-farm income activities was dominated by non-market participants, which accounts $66 \%$ and the remaining $34 \%$ was market participant farmers. The result of chi-square shows that non-farm income was statistically significant at $5 \%$ significance level. A farmer who engages in non-farm activities reduces the volume of production. This implies that the reduction of the volume of production decreases the market participation of farmers.

In terms of educational status of household head, the educational background of the sample household heads is believed to be an important feature that determines the readiness of household head to accept new ideas and innovations. More educated farmers are expected to adopt new technologies to increase their land and labour productivities. The result indicates that $47.7 \%$ of market participants were illterate, $17.3 \%$ was read and wright, $10.7 \%$ was primary school and $6 \%$ was secondary school and above. On the other hand, $14 \%$ of non-market participants were illiterate, $5.3 \%$ was read and wright,. $7 \%$ was primary school and $1.3 \%$ was secondary school and above. The overall educational status of the sample respondents were dominated by literate which accounts $52.6 \%$ (not only include a farmer to attained formal education but also they attained informal education or read and write) and the remaining $47.4 \%$ were illiterate. The result of chi-square shows that educational status of sample households was statistically insignificant meaning that educational status was not affect the market participation of sample households.

Table 3. Demographic and Socio-economic characteristics of target respondents for categorical variables

\begin{tabular}{|c|c|c|c|c|c|c|c|c|}
\hline \multirow{2}{*}{\multicolumn{2}{|c|}{ Variables }} & \multicolumn{2}{|c|}{$\begin{array}{l}\text { Market } \\
\text { Participation }\end{array}$} & \multicolumn{2}{|c|}{$\begin{array}{l}\text { Non market } \\
\text { Participation }\end{array}$} & \multicolumn{2}{|c|}{ Over all } & \multirow[t]{2}{*}{$\chi^{2}$-test } \\
\hline & & Freq & $\%$ & & & Freq & $\%$ & \\
\hline Sex & $\begin{array}{l}\text { male } \\
\text { Female }\end{array}$ & $\begin{array}{l}92 \\
26\end{array}$ & $\begin{array}{l}61.33 \\
17.33\end{array}$ & $\begin{array}{l}14 \\
11\end{array}$ & $\begin{array}{l}21 \\
7.3\end{array}$ & $\begin{array}{l}113 \\
37\end{array}$ & $\begin{array}{l}75.3 \\
24.7\end{array}$ & 2.0632 \\
\hline \multirow{2}{*}{$\begin{array}{l}\text { Access to credit } \\
\text { Improved } \\
\text { input use }\end{array}$} & $\begin{array}{l}\text { Yes } \\
\text { No }\end{array}$ & $\begin{array}{l}65 \\
53\end{array}$ & $\begin{array}{l}43.3 \\
35.3\end{array}$ & $\begin{array}{c}16 \\
16\end{array}$ & $\begin{array}{l}10.7 \\
10.7\end{array}$ & $\begin{array}{l}81 \\
69\end{array}$ & $\begin{array}{l}54 \\
46\end{array}$ & .262 \\
\hline & $\begin{array}{l}\text { Yes } \\
\text { No }\end{array}$ & $\begin{array}{l}80 \\
38\end{array}$ & $\begin{array}{l}53.3 \\
25.3\end{array}$ & $\begin{array}{l}13 \\
19\end{array}$ & $\begin{array}{c}8.7 \\
12.7\end{array}$ & $\begin{array}{l}93 \\
57\end{array}$ & $\begin{array}{l}62 \\
38\end{array}$ & $7.9^{* * *}$ \\
\hline $\begin{array}{l}\text { Access to market } \\
\text { Information }\end{array}$ & $\begin{array}{l}\text { Yes } \\
\text { no }\end{array}$ & $\begin{array}{l}101 \\
17\end{array}$ & $\begin{array}{l}67.3 \\
11.3\end{array}$ & $\begin{array}{l}22 \\
10\end{array}$ & $\begin{array}{c}14.7 \\
6.7\end{array}$ & $\begin{array}{l}123 \\
27\end{array}$ & $\begin{array}{l}82 \\
18\end{array}$ & $4.84 * *$ \\
\hline $\begin{array}{l}\text { Extension service } \\
\text { On marketing }\end{array}$ & $\begin{array}{l}\text { Yes } \\
\text { No }\end{array}$ & $\begin{array}{l}59 \\
59\end{array}$ & $\begin{array}{l}39.3 \\
39.3\end{array}$ & $\begin{array}{l}6 \\
26\end{array}$ & $\begin{array}{c}4 \\
17.3\end{array}$ & $\begin{array}{l}65 \\
85\end{array}$ & $\begin{array}{l}43.3 \\
56.7\end{array}$ & $10.01 * * *$ \\
\hline Nonfarm income & $\begin{array}{l}\text { Yes } \\
\text { No } \\
\end{array}$ & $\begin{array}{l}34 \\
84 \\
\end{array}$ & $\begin{array}{l}22.7 \\
56 \\
\end{array}$ & $\begin{array}{c}17 \\
15\end{array}$ & $\begin{array}{l}11.3 \\
10\end{array}$ & $\begin{array}{l}51 \\
99\end{array}$ & $\begin{array}{l}34 \\
66 \\
\end{array}$ & $6.6304 * *$ \\
\hline Education level & $\begin{array}{l}\text { Illiterate } \\
\text { Read and Wright } \\
\text { Primary } \\
\text { Secondary and } \\
\text { above }\end{array}$ & $\begin{array}{l}67 \\
26 \\
16 \\
9\end{array}$ & $\begin{array}{c}44.7 \\
17.3 \\
10.7 \\
6\end{array}$ & $\begin{array}{c}21 \\
8 \\
1 \\
2\end{array}$ & $\begin{array}{r}14 \\
5.3 \\
.7 \\
1.3\end{array}$ & $\begin{array}{c}88 \\
34 \\
17 \\
11\end{array}$ & $\begin{array}{l}58.7 \\
22.7 \\
11.4 \\
7.3\end{array}$ & 2.92 \\
\hline
\end{tabular}

Note: $* * *, * * \quad$ indicate at $1 \%, 5 \%$ and significance level in sequence.

Source: own survey, 2018

\subsection{Econometrics Result}

Before running Heckman two-step selection model, multicollinearity test was carried out. The effects of continuous explanatory variables were checked for multicolinearity using Variance Inflation Factor (VIF) while Contingency Coefficients were used to check the degree of association among the categorical explanatory variables. According to the results no significant problems of multicolinearity and very high degree of association were observed, because the value of VIF and CC were less than 10 and 0.75 respectively.

\subsubsection{Factors influencing market participation}

To determine the factors that influence market participation of chickpea in Dembia district, a probit model was estimated in the first stage of Heckman two-step selection equation.

The age of household head could determine their decision of market participation positively as indicated Table 4. This was from the point of view of the experience that they could acquire through time. However, the 
opposite was revealed from the result. The age of household head had negatively and significantly influence significantly influences the farmers' decision to participate in chickpea marketing at $5 \%$ level of significance.

It indicates that as the age of the household head increases by a year, it decreases the probability of farmers to participate in chickpea marketing by $1.05 \%$, all other factors held constant. This is because when households get older and older, they tend to rent out their land or they shift to the production of lesser labour intensive farming alternatives or the younger people are more receptive to new ideas and are less risk averse than the older people. This finding is in line with (Adugna, 2009) found that age of household head had negative and significance influence on farmers' decision of chickpea market participation.

Quantity of chickpea produced: the influence of amount of chickpea produced on the farmer's decision to participate in chickpea marketing was as predicted in the original hypothesis. The total annual quantity of chickpea produced in a year had positively and significantly influence the farmers' decision to participate in chickpea marketing at $1 \%$ level of significance. It indicates that a household who produce more quantity of chickpea had also probability of farmer's to participate in chickpea marketing. The result reveals that the amount of chickpea produced by the farmer increases by one quintal, it increases the probability of farmers to participate in chickpea marketing by $2.54 \%$, all other factors held constant. This is in line with the findings of (Rehima, 2006), (Assefa, 2009), (Ayelech, 2011), (Muhammed, 2011) and (Abraham, 2013) found that the amount of pepper, honey, avocado and mango, Teff and wheat, and Vegetables (potato, cabbage and tomato), respectively, produced by farmers/households influence farmer's decision on market participation for each commodity positively and significantly. Hence, the amount of chickpea produced by households is one of the major factors that determine the farmer's decision to participate in marketing.

Non-farm income: the influence of nonfarm income on the farmer's decision to participate in chickpea marketing was as predicted in the original hypothesis. Non-farm incomes had negatively and significantly influence the farmers' decision to participate in chickpea marketing at $5 \%$ level of significance. It indicates that a household who has nonfarm income can easily generate income these decrease farmer's decision to participate on chickpea marketing. The result reveals that a farmer who has nonfarm income it decreases the probability of farmer's to participate in chickpea marketing by $14.9 \%$, all other factors held constant.(Rehima,2007) who found that if pepper producer have non-farm income, the probability of market participation decreases.

Land size: similar to as expected, land size had been positively and significantly influences the farmers' decision to participate in chickpea marketing and statistically significant at $5 \%$ significance level. This indicates that as the number land size increased by one hectare, it increases the probability of farmers to participate in chickpea marketing by $6.33 \%$, all other factors held constant. This finding is in line with (Bosena, 2008) found that size of landholding of household head had positive and significance influence on farm market participation of cotton in Metema district.

Chickpea farming experience: similar to as expected, farming experience has been positively and significantly influences the farmers' decision to participate in chickpea marketing and statistically significant at $5 \%$ significance level. This indicates that as the experience increased by one year, it increases the probability of farmers to participate in chickpea marketing by $0.9 \%$, all other factors held constant. The reason behind is obvious Farmers with longer production experience are expected to be more knowledgeable and skillful and then would most probably on decision of farmer's on chickpea market participation. The result from (Abraham, 2013) implied that as farmers have high potato production experience the farmer's increased through its effect on potato production.

Market information: similar to as expected, market information has been positively and significantly influences the farmers' decision to participate in chickpea marketing and statistically significant at $5 \%$ significance level. . The result reveals that a farmer who has market information it increases the probability of farmer's to participate in chickpea marketing by $20.67 \%$, all other factors held constant. Because, producers that have access to market information are likely to participate in the market. (Jari and Fraser, 2009) stated that availability of market information boosts confidence of household who are willing to participate in the market. Poor access to market information results in information-related problem, namely moral hazard and adverse selection which in turn increase transaction costs and hence discourages participation in the market by some farmers.

\subsubsection{Factors influencing the extent of market participation}

To determine factors influencing volume of sale in chickpea marketing, OLS regression was estimated in the second stage of Heckman two-step of outcome equation.

Quantity of chickpea produced: the influence of amount of chickpea produced on the extent of chickpea market was as predicted in the original hypothesis. The total annual quantity of chickpea produced in a year had positively and significantly influence the quantity of chickpea supplied to the market at $1 \%$ level of significance (Table 4). It indicates that a household who produce more quantity of chickpea had also supplied more to the market or when the production of chickpea in a given year is better, the higher the market supply and the amount of chickpea that can be sold to the market.

The result reveals that the amount of chickpea produced by the farmer increases by one quintal, the quantity of chickpea supplied to the market increases by 0.82 quintal, all other factors held constant. This is in line with the 
findings of (Rehima, 2006), (Assefa, 2009), (Ayelech, 2011), (Muhammed, 2011) and (Abraham, 2013) found that the amount of pepper, honey, avocado and mango, Teff and wheat, and Vegetables (potato, cabbage and tomato), respectively, produced by farmers/households influence quantity of supplied to the market for each commodity positively and significantly. Hence, the amount of chickpea produced by households is one of the major factors that determine the volume of chickpea supplied to the market.

Non-Farm income: the influence of nonfarm income on the farmer's market supplied in chickpea marketing was as predicted in the original hypothesis. Nonfarm incomes had negatively and significantly influence the volume of chickpea marketing at $1 \%$ level of significance. It indicates that a household who has nonfarm income can easily generate income these decrease the volume of chickpea supplied. The result reveals that a farmer who has nonfarm income it decreases the volume of sale by 1.18 quintal, all other factors held constant. (Rehima, 2007) who found that if pepper producer have non-farm income, the amount of pepper supplied to the market decreases.

Lagged market price: Lagged price of chickpea was hypothesized to affect the volume of chickpea supplied to the market and found to be positive and statistically significant at 5\% significance level. The positive and significant relationship indicates that as the last year price of chickpea at the market raised by one birr the quantity of chickpea supplied to the market also rises by 0.0013 quintal the next year.

In support of the findings of (Ayelech, 2011) on market chain analysis of fruits found that significant positive relationship between last year fruit price and quantity of fruits supplied to the market.

Education level: Education has showed positive effect on chickpea quantity supplied to market with significance level of $5 \%$. The survey results revealed that, if the education level increase by one year, the amount of chickpea supplied to the market increases by 0.46 quintal, keeping other factors constant. This may be because majority of the farmers in the study area are at low level of education and thus not enable them to have better skills and better access to information to supply more chickpea to market. This is also in line with previous study of (Ayelech 2011), who found that if avocado producer gets educated, the amount of avocado supplied to the market increases. (Amare, 2013) also reported that education level of farmers exhibited a significant and positive effect on the marketed surplus of pepper.

Inverse mills ratio: the inverse mills ratio influences the extent of market participation positively and significantly at $10 \%$ level of significance. This indicates that there is sample selection bias; which implies the existence of some unobservable farming characteristics responsible for farmers' likelihood to participate and thereby the quantity of chickpea supplied to the market. Or the error term in the selection and primary equation is positively correlated; which implies that unobserved factors that make participation in chickpea marketing are more likely to be associated with higher scores on the amount of chickpea marketed.

Table 4: The Heckman two-step equation result

\begin{tabular}{|c|c|c|c|c|}
\hline \multicolumn{3}{|c|}{ Heckman two step selection equation result } & \multicolumn{2}{|c|}{ Heckman two step outcome equation result } \\
\hline Variables & Marginal effect & Std.Err & Coefficients & St.error \\
\hline quantity of chickpea produced & $.0257572 * * *$ & .049 & $.8188075 * * *$ & .051 \\
\hline Non-farm income & $-.1494527 * *$ & .350 & $-1.182919 * * *$ & .401 \\
\hline Extension service on marketing & .0096525 & .392 & .5250621 & .392 \\
\hline Distance from the nearest market & -.0010004 & .006 & .0059845 & .006 \\
\hline Market information & $.206709 * *$ & .460 & -.1840775 & .546 \\
\hline Access to credit & .0071211 & .360 & -.1123795 & .403 \\
\hline Improved input use & -.0439792 & .415 & -.1477653 & .514 \\
\hline Lagged market price & .0001071 & .001 & $.0012542 * *$ & .0005 \\
\hline Total livestock unit & .002585 & .081 & .0764006 & .060 \\
\hline Education level & -.0205851 & .222 & $.4564959 * *$ & .198 \\
\hline Land size & $.0601633 * *$ & .199 & .2183053 & .202 \\
\hline Farming experience & $.009214 * *$ & .031 & .0240698 & .037 \\
\hline Age & $-.0103206^{* *}$ & .032 & -.0569434 & .037 \\
\hline Sex & .0434076 & .375 & .1937549 & .394 \\
\hline Family size & -.0103287 & .088 & & \\
\hline Mills lambda(IMR) & & & $1.563343 *$ & .883 \\
\hline \multirow[t]{2}{*}{ Cons } & & 1.163 & -2.394941 & 1.364 \\
\hline & & & \multicolumn{2}{|c|}{$\begin{array}{ll}\text { Number of observation }= & 150 \\
\text { Censored observation }= & 32 \\
\text { Uncensored observation }= & 118 \\
\text { Wald chi2 }(14)=779.04 & \\
\text { Prob }>\text { chi } 2=0.0000 & \end{array}$} \\
\hline
\end{tabular}

Note $* * *, * * *$ at $1 \%, 5 \% \& 10 \%$ significance level respectively

Source: own survey, 2018 


\section{CONCLUSIONS AND RECOMMENDATIONS}

\subsection{Conclusions}

Chickpea production in Dembia district has increased significantly for the past years. It has significant contribution in annual households' income, source of food, health and rural employment. Factors affecting chickpea market participation and extent of sale were analyzed by heckman two step selection models. As the result indicates, the age of household head and non-farm income have affected market participation decision and volume of sale negatively and significantly while education level of the household head, access to market information, farming experience, land allocated to chickpea and lagged market price have been influenced market participation and volume of supply positively and significantly.

\subsection{Recommendations}

Quantity of chickpea produced influences volume of market participation positively. Hence the government should support farmers by providing improved inputs like fertilizer and improved seed at a proper time with the right price. The amount of chickpea marketed and market participation decision were negatively influenced by the nonfarm income. Thus in order to scale up the volume of chickpea that can be sold to the market, extension activities should focus on educating farmers to practice specialized farming system. Education level of the household head influenced volume of sale positively. Hence, appropriate policies should be designed to provide adequate and effective basic educational opportunities to the rural farming households in general and to the study area in particular. In this regard, the regional and local government should strengthen the existing provision of formal and informal education through facilitating all necessary materials. Land allocated to chickpea affected market participation decision and volume of sale positively. Therefore, policies that can enhance efficient utilization of the existing limited farm land can be taken as an alternative. This may include the consolidation and efficient utilization of existing unutilized land in the area. At the same time, regional and local governments should also give due attention to promoting the use of agricultural inputs among small farmers through designing especial programs that take such variation into account.

\footnotetext{
Abbreviations

GDP: Gross Domestic Product, UNDP: United Nation Development Program, CSA: Central Statistical Authority, TLU: Tropical Livestock Unit, VIF: Variance Inflation Factor, CC: Contingency Coefficient, OLS: Ordinary Least Square, DDARDO: Dembia District Agricultural and Rural Development Office.

\section{Acknowledgements}

The authors are appreciative ministry of education and Wollega University for their opportunity creation to do this research work. Furthermore, we would like to acknowledge enumerators and Dembia district respondents of the study for their valuable information to the achievement of our objectives.

Funding

Authors have not gotten direct fund for this research work.

Availability of data and materials

The raw data which confirm the output of this study can be found from the authors based on permissible request. Authors' contributions

The notion and plan of the study was made by all authors. All of the authors had been engaged for this paper improvement. The first author carried out the data analysis and write-up. The second author read and reviewed it well.

Competing interests

There are no competing interests.
}

\section{REFERENCE}

Abay Akalu. (2007). Vegetable Market Chain Analysis: The Case of Fogera District in ANRSof Ethiopia. An Msc. Thesis Presented to the School of Graduate Studies of Haramayaof graduate studies, Haramaya University. pp129.

Abraham Tegegn. (2013). Value chain analysis of vegetables: the case of Habro andKombolcha Woredas in Oromia Region, Ethiopia. M.Sc thesis presented to the schoolof graduate studies, Haramaya University. pp129.

Adugna Gessesse. (2009). Analysis of fruit and vegetable market chains in alamata, southernzone of Tigray: the case of onion, tomato and papaya. An MSc Thesis Presented toSchool of Graduate Studies of Haramaya University. pp98.

Assefa A. (2009). Market Chain Analysis of Honey Production: In Atsbi Wemberta DistrictEastern Zone of Tigray National Regional State. MSc. Thesis Haramaya University.

Astewel Takele. (2010). Analysis of rice profitability and marketing chain: The case of Fogera District, South Gondar Zone, Amhara National Regional State, Ethiopia. M.Sc thesispresented to School of Graduate Studies, 
Haramaya University. 76p.

Ayelech Tadesse. (2011). Market chain analysis of fruits for Gomma woreda, Jimma zoneOromia National Regional State. M.Sc thesis presented to School of Graduate Studies,Haramaya University. p110.

Bekele. (2007). Structure and functioning of chickpea markets in Ethiopia: Evidence based on analyses of value chains linkingsmallholders and markets. Improving Productivity and Market Success (IPMS) ofEthiopian Farmers Project Working Paper 6. ILRI (International Livestock Research Institute), Nairobi, Kenya., p. 66pp.

Bossena Tegegne. (2008). Analysis of Cotton Marketing Chains: The Case of Metema Woreda,North Gondar Zone, Amhara National Regional State an Msc. Thesis Presented ToThe School Of Graduate Studies Of Haramaya University.

Central Statistics Authority-Ethiopia. (2015). Report on area and production of crops. Statistical bulletin. 1:578 589.

Cochran WG. (1977). Sampling Techniques, 2nd Ed.,New York: John Wiley and Sons, Inc.

CSA (Central Statistical Agency. (2014). Area and production of major crops (privatepeasant holding, Meher Season). Report volume I, central statistical agency (CSA),Addis Ababa, Ethiopia.

CSA. (2015). Report on area and production of crops. Statistical bulletin, 1:578 - 589.

Desalegn Haileyesus. (2019). Adoption of wheat-chickpea double cropping and its impact on yield and farm income in becho woreda, south west shoa zone, Oromia Region, Ethiopia. Master of Arts in rural livelihood $\&$ development Addis Ababa, Ethiopia.

DDAO (Dembia District Agriculture Office). (2017). Draft report on cereal crops production and productivity of $2016 / 17$

DDAO(Dembia District Agriculture Office). (2017). Draft report on agriculture production and productivity and agro ecology of Dembia district.

DDFEDO (Dembia District Finance and Economic Development Office). (2017). Working paper of Dembia district agro-ecology and its habitat.

Geoffrey. K. (2014). Determinants of market participation among small-scale pineapplefarmers in Kericho County, Kenya. M.Sc thesis presented to the school of graduatestudies, Egerton University.

Gujarati D.N. (2004). Basic Econometrics.4PthP edition. McGraw-Hill, New York. 6. pp. 563-63.

Heckman J.J. (1977). Sample selection bias as a specification error, Econometric.

James Warne, Tim Stehulak, and Leulsegged Kasa. (2015). Woreda-Level Crop Production Rankings in Ethiopia: A Pooled Data Approach. International Food Policy Research Institute (IFPRI) Addis Ababa, Ethiopia.

Jari, B and Fraser, C.G. (2009). An Analysis of Institutional and Technical Factors Influencing Agricultural Marketing amongst Smallholder Farmers in the Kat River Valley,Eastern Cape, South Africa. African Journal of Agricultural Research, 4 (11):. 1129-1137.

Kinde Aysheshm. (2007). Sesame market chain analysis: the case of Metema Woreda, North Gondar Zone, Amhara National Regional State. An MSc Thesis Presented to Schoolof Graduate Studies of Haramaya University. 123p.

Menale Kassie, Bekele Shiferaw and Murich, G. (2010). Adoption and impact of improvedgroundnut varieties on rural poverty: Evidence from rural Uganda. Environment forDevelopment (EFD), Discussion working paper, May 2010 EfD DP 10-11.

Muhammed. (2011). Market chain analysis of teff and wheat production in halaba special woreda, southern Ethiopia. M.Sc thesis submitted to the School of Graduate Studies, Haramaya

Rehima Musema. (2007). Analysis of red pepper marketing: the case of Alaba and Silitie inSNNPRS of Ethiopia. An MSc Thesis Presented to School of Graduate Studies ofHaramaya University. 153p.

TL-III (Tropical Legumes III. (2016). Chickpea production, technology adoption and marketlinkages in Ethiopia. Pan-Africa grain legume and world cowpea conferenceFeb 28- Mar 4, 2016, Livingstone, Zambia.

UNDP (United Nations Development Program. (2015). Ethiopia: Key economic and socialindicators. Report No. 2, 2015, UNDP Ethiopia, Addis Ababa, P.O.Box 5580.

UNDP (United Nations Development Program). (2016). OECD (Organization for EconomicCooperation and Development) and AFDB (African Development Bank2016. African Economic Outlook, Ethiopia. Report. 